\title{
医療機器の新しいEMC 規格
}

\author{
谷川 廣治*
}

The New EMC Standard for Medical Devices

Kowji TANIKAWA*

*オリンパス光学工業株式会社医療システムカンパニー（テ192-8705 東京都八王子市石川町 2951）

* Medical Systems Group, OLYMPUS Optical Co., Ltd. (2951 Ishikawa-cho, Hachioji-shi, Tokyo 192-8705)

\section{1. はじめに}

医療機器の製造・販売には国家レベルの承認が必須と なっている。このために各国には医療機器規制があり, 安 全性に関して規制がされ，最近の傾向として EMC 規制が 取り込まれている。医用電気機器の安全性規格はIEC 60601-1が，EMC規格としては副通則の IEC 60601-1-2 が用 いられている。

平成 7 9 年の不要電波問題対策協議会（不要協）による 携帯電話の影響調查を経て「携帯電話端末等の使用に関す る指針 (不要協指針)」が発行され，またヨーロッパEUに よる医療機器規制 $(M D D)$ 施行を受けて，平成 10 年から日 本医療機器関係団体協議会 (日医機協) EMCガイドライ ンの運用による自主規制（IEC 60601-1-2: 1993 適合）が始 まった。この自主規制によって平成 10 年 6 月から平成 14 年 3 月までに 1600 機種を超える新製品が適合を果たした。

平成12１4年にかけて電波産業会(ARIB)による再度の影 響調査が実施され，第3世代携帯電話など新しい無線利用 機器に対しても不要協指針が有効であることが示された。

また，この間に国内における医用電気機器の EMC 適合 が法制化された。国際的にはEMC 規格の第 2 版が発行さ れ，EUおよび米FDAの取り組みも明らかになってきた。

主として医療機器の $\mathrm{EMC}$ 規格第 2 版の内容と動向，およ び個別医療機器の事情を反映した個別規格について述べ る。

\section{EMC 規格適合の法制化}

現在，ヨーロッパではMDD, アメリカではFDAにより医 療機器の EMC 規制が行われるなど，各国で EMC 規格への 適合が求められている。EMC規格としては世界的に IEC 60601-1-2: 1993（第1版）が使用されている。我が国におい ても医療機器の EMC 規格(JIS T 0601-1-2: 2002) が制定され, 平成 14 年 8 月 30 日付, 厚生労働省通知（医薬審発第 0830006 号）が発出されて薬事法による EMC 規格適合が始 まった。この JISは IEC 60601-1-2: 1993（EMC 規格第 1版）
と同一内容である。

医療機器は製造承認申請時に承認申請書に EMC 規格適 合を示す資料を添付して承認を受けることになっている。 規格適合に必要な $\mathrm{EMC}$ 試験データは自社データを含む「試 験を適正に実施する能力を有する試験所」のデータである こと, 国内での定格電源電圧での試験データであることが 要求される。医療機器のクラスに応じて表 1 の日程に従っ て強制化される。表 1 に示すように既承認機器にも強制適 用が実施される日，すなわち，EMC規格未適合機器は販売 ができなくなる日が設定されている。

\section{$2.1 E M C$ 規格適合の表示}

通知には具体的な表示について示されていないので，日 医機協では「EMC 規格適合表示基準（表示ガイドライン）」 を制定して業界の統一表示を行うこととした。この適合表 示は業界の自主的なものであり，異なる表示をする企業， 医療電気機器もありうる。

表 1. 法制化の主要な日程

\begin{tabular}{|c|c|c|}
\hline $\begin{array}{c}\mathrm{EMC} \text { 規格適合 } \\
\text { 施行日 }\end{array}$ & $\begin{array}{c}\text { 新規承認申請 } \\
(\text { 一変を除く) } \\
\text { (すなわち, 強制施行日) }\end{array}$ & $\begin{array}{c}\text { 既承認済, または中請中 } \\
\text { (すなわち, 未対応機器 } \\
\text { の販売中止日） }\end{array}$ \\
\hline クラス IV & 平成 15 (2003) 年 10 月 1 日 & 平成 18 (2006)年 04 月 1 日 \\
\hline クラス III & 平成 16 (2004)年 04 月 1 日 & 平成 18 (2006)年 10 月 1 日 \\
\hline クラス II & 平成 16 (2004)年 10 月 1 日 & 平成 19 (2007)年 04 月 1 日 \\
\hline $\begin{array}{l}\text { クラス I } \\
\text { 承認不要 }\end{array}$ & \multicolumn{2}{|c|}{ 平成 19 (2007)年 04 月 1 日 } \\
\hline
\end{tabular}

クラスの説明

医療機器を，患者に対するリスクの大小によって分類する考え方。

クラスIV：心臟ペースメーカなどに代表される人体内に埋め込まれ，不具 合が生じた場合に生命の危険に直結する医療機器

クラス III : レーザメスなど, 治療機器を主とする生命の危険, 重大な機能 障害に直結する可能性が低いとは考えられない医療機器

クラス II ：MRIなど，診断を主とする生命の危険，重大な機能障害に直結 する可能性は低いと考えられる医療機器

クラス I : 電子聴診器なよ゙人体に重大な危険を与える可能性が低いと考え られる医療機器

承認不要：家庭用電気マッサージ器など 
適合マーク：「EMC 適合」という文字を枠線で囲ったもの

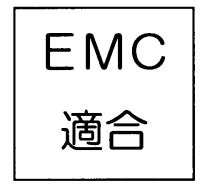

\section{EMC適合}

日医機協のガイドラインではあるが，広く医療電気機器 製造企業に使用してもらい，さまざまな適合マークが生じ ることのないように，日医機協加盟の各工業会，団体に加 入していない企業，海外企業などを排除することにもなり かねない特別なマークのデザインや規定を避け，適合を示 す文字表示のみとした。書体，サイズ，色などは問わない。

取り扱い説明書や添付文書には適合規格番号，規格制定 年を記載することになっている。

\section{3. 医用電気機器 EMC 規格とIEC/CISPR のEMC一般 規格}

1993年発行の医用電子機器 EMC 規格（IEC 60601-1-2: 1993 第1版）はもとより，2001年制定の第2版においても 具体的な試験方法, 許容值基準などについて IEC/CISPR の $\mathrm{EMC}$ 規格（一般規格）を採用している（次ページ表2）。 IEC 61000-3 シリーズ規格およびCISPR 11 のエミッション規 格，IEC 61000-4 シリーズ規格のイミュニティ規格で構成さ れている。これらの規格は主として IEC/TC77 委員会で審 議・制定されているが，情報機器をはじめ多くの産業機器 などの規格と共通である。IEC 60601-1-2 は製品群規格と呼 ばれ，医療機器としての許容值基準，特例などを定めてい る。

\subsection{IEC 60601-1-2: 2001 第2版の検討経緯}

第1版が 1993 年発行後， 5 年後の見直しのためにドラフ 卜の作成検討が 1994 年 6 月始まった。紆余曲折を経て, 2001年11月 1 日にやっとIEC60601-1-2: 2001 第2版が正式発 行された。

第 2 版発行は第1版からすでに 8 年が経過している。この 間に携帯電話等の爆発的な普及が規格内容の修正を促し続 けたことも長時間を要した理由の 1 つと考えられる。現在 は無線LANをはじめとしてETC（自動料金徵収システム）, EAS（盗難防止機器）などの新しい無線利用システムの開 発・導入が開始されている。また，屋内の商用電源ライン にインターネットなどの高速通信を重畳する試みや大電力 を使用する $\mathrm{IH}$ 調理器など新たな電磁環境の提案も目立つ。 院内機器のみならず在宅機器にまで EMC 対応の強化が必 要となってくる。これらを勘案すると第 3 版の早期制定も 想定される。

\subsection{IEC 60601-1-2: 2001 第2 版の概要}

端的に言えば，試験項目も増え，試験内容も厳しくなっ て,「広く, 深く」なった。試験に必要な時間, 費用など はおよそ2 倍以上と見積むられる。また，付帯文書などの 準備に要する工数も大幅に増加するものと思われる。また，
試験周波数範囲でいえば，従来カバーしていなかった携帯 電話，無線LANなどの領域にまで拡大したことが特徴であ る。

\section{2 .1 リスク分析の導入}

安全を最優先とする医療機器ではあるが，治療効果と安 全性のトレードオフを考慮する必要もある。第2 版の最大 の特徴点は「リスク分析」の導入である。これまでもイ ミュニティの判定基準などに「臨床的に重要な利益」(Clinical Benefit, Clinical Utility)などの表現で, 医療電気機器と しての主要機能とその他の付帯機能を区別することが試み られた。概念的な整合を改善してわかりやすい規格表現に するためにCD2では「重要な機能」(Critical Function)とい う定義に変え，これは「リスク分析」を用いて抽出するこ とになった。しかしながら，わかりにくさが相変わらず見 られ，この点の改善をした結果，「基本性能」*1 (Essential Performance) という定義に修正された。どのレベルまで分 析するのか, 分析結果を誰が, どのように判断するのか等, まだ不明な点は多いものの，IEC 60601-1第3版などでも採 用される手法や定義の採用によって規格間の整合性が出て きた。今後, ISO14971-1 (JIS Q 14971-1)「リスク分析の適 用」, ISO 14971 (JIS Q 14971)「医用機器のリスクマネジメ ント」を用いて明確にしていく方向性が示された。

「基本性能」についてはエミッション試験，イミュニティ 試験ともに適用することになるが，もしリスク分析が実施 されないならすべての機能は「基本性能」とみなされて本 規格（IEC60601-1-2第2版）の試験がすべて適用される。

また，医用システムに接続される情報機器など非医用電 気機器については「基本性能」に影響を与えない場合に は，その非医用電気機器の EMC 国際規格を適用すること で，本規格の適用は免除される。「基本性能」に影響を与 えない,という判断はリスク分析によって行われる。

今後はリスク分析およびリスク評価における機器間，企 業間，試験機関間などのレベル合わせが重要になってくる。 機能も目的も異なる多くの医用電気機器のリスク分析に対 するガイドライン作りを進める必要がある。

\section{2 .2 試験項目の概要と解説}

(1) エミッション試験項目

(1)電磁界エミッション：CISPR 11, 14, 15, 22

MRI, CTなど遮蔽室内でのみ使用する機器／システムは 第1 版では無条件に $12 \mathrm{~dB}$ の緩和が認められた。第 2 版では 緩和条件が変更され，20 dB以上の電磁遮蔽効果を有する 遮蔽について最小遮蔽効果值（最小 $20 \mathrm{~dB}$ ) 分までの緩和 が認められることになった。この遮蔽効果は当初 $80 \mathrm{MHz}$

脚注 ※1：IEC60601-1第3版での定義

3.30 「基本性能」(ESSENTIAL PERFORMANCE) 残存リスクを許 容限度内に収めるために必要な性能特性。

3.109 「残存リスク」(RESIDUAL RISK)予防手段を講じて後に 残ったリスク。 
表 2. IEC60601-1-2 の概要 第 1 版と第 2 版の比較

\begin{tabular}{|c|c|c|c|}
\hline 項 目 & 規 格 & 第 1 版 & 第2版 \\
\hline 電磁界エミッション & $\begin{array}{l}\text { CISPR 11, 14, } \\
15,22\end{array}$ & $\begin{array}{l}\mathrm{X} \text { 線遮蔽室内の永久設置機器は } \\
12 \mathrm{~dB} \text { 緩和 }\end{array}$ & $\begin{array}{l}\text { 遮蔽室内でのみ使用する機器またはシ } \\
\text { ステムは遮蔽効果值に応じて紘和。た } \\
\text { だし, 最小 } 20 \mathrm{~dB} \text { 遮蔽効果が確保され } \\
\text { ている場合にのみ適用される。 }\end{array}$ \\
\hline 高調波丕 & IEC $61000-3-2$ & 適用しない & $\begin{array}{l}\text { 各相 } 16 \mathrm{~A} \text { 以下, かつ, 定格電圧 } 220 \mathrm{~V}, \\
230 \mathrm{~V}, 240 \mathrm{~V} \text { の機器に適用する。 }\end{array}$ \\
\hline 電源変動, フリッカー & IEC 61000-3-3 & 適用しない & $\begin{array}{l}\text { 各相 } 16 \mathrm{~A} \text { 以下， かつ，定格電圧 } 220 \mathrm{~V}, \\
230 \mathrm{~V}, 240 \mathrm{~V} \text { の機器に適用する。 }\end{array}$ \\
\hline イミュニティ判断基準 & & $\begin{array}{l}\text { 危害が生じないか, または, 危害が } \\
\text { 生じず製造業者の指定した機能を維 } \\
\text { 持する。 }\end{array}$ & $\begin{array}{l}\text { 「基本性能」(Essential Performance)を } \\
\text { 与え, かつ, 安全が維持できなければ } \\
\text { ならない。基本性能に対する劣化は認 } \\
\text { めない。 }\end{array}$ \\
\hline 静電気放電 & IEC $61000-4-2$ & $\begin{array}{ll}\text { 気中放電 } & 8 \mathrm{kV} \\
\text { 接触放電 } & 3 \mathrm{kV}\end{array}$ & $\begin{array}{l}\text { 気中放電 } \pm 2 \mathrm{kV}, \pm 4 \mathrm{kV}, \pm 8 \mathrm{kV} \\
\text { 接触放電 } \pm 2 \mathrm{kV}, \pm 4 \mathrm{kV}, \pm 6 \mathrm{kV} \\
\text { (静電気放電に敏感な部品の表示があ } \\
\text { る部分に対しては, 気中放電の試験を } \\
\text { 適用しない。図記号を表示する) }\end{array}$ \\
\hline 放射 RF 電磁界 & IEC 61000-4-3 & $\begin{array}{l}3 \mathrm{~V} / \mathrm{m}(26 \mathrm{MHz} \sim 1 \mathrm{GHz}) \\
\mathrm{X} \text { 線遮蔽室内でのみ使用する機器は } \\
1 \mathrm{~V} / \mathrm{m}\end{array}$ & $\begin{array}{l}3 \mathrm{~V} / \mathrm{m}(80 \mathrm{MHz} 2.5 \mathrm{GHz}) \\
\text { 生命維持機器は } 10 \mathrm{~V} / \mathrm{m} \\
\text { 遮蔽室内でのみ使用する機器またはシ } \\
\text { ステムは遮蔽効果值に応じて緩和。た } \\
\text { だし, 最小 } 20 \mathrm{~dB} \text { の遮蔽効果が確保され } \\
\text { ている場合にのみ適用される。 }\end{array}$ \\
\hline $\begin{array}{l}\text { ファーストトランジェ } \\
\text { ントノバースト }\end{array}$ & IEC 61000-4-4 & \begin{tabular}{|ll} 
電源ライン & $\pm 1 \mathrm{kV}$ \\
永久設置機器 & $\pm 2 \mathrm{kV}$ \\
$3 \mathrm{~m}$ 以上の信号線 & $\pm 0.5 \mathrm{kV}$
\end{tabular} & $\begin{array}{l}\text { 電源ライン } \pm 2 \mathrm{kV} \\
\text { 信号線 } \pm 1 \mathrm{kV} \\
\text { (患者結合線, } 3 \mathrm{~m} \text { 未満の信号線には適 } \\
\text { 用しない) } \\
\text { (定格電源電圧が複数, または範讲が } \\
\text { ある場合には, 取大, 最小電圧で試験 } \\
\text { する) }\end{array}$ \\
\hline サージ & IEC $61000-4-5$ & \begin{tabular}{|ll} 
差動モード & $\pm 1 \mathrm{kV}$ \\
同相モード & $\pm 2 \mathrm{kV}$
\end{tabular} & $\begin{array}{l}\text { 差動モード } \pm 0.5 \mathrm{kV}, \pm 1 \mathrm{kV} \\
\text { 同相モード } \pm 0.5 \mathrm{kV}, \pm 1 \mathrm{kV}, \pm 2 \mathrm{kV} \\
\text { (定格電源電圧が複数, または範囲が } \\
\text { ある場合には, 最大, 最小電圧で試験 } \\
\text { する) }\end{array}$ \\
\hline $\begin{array}{l}\text { 電圧ディップ, 瞬断, } \\
\text { 電圧変動 }\end{array}$ & IEC $61000-4-11$ & 検討中 & 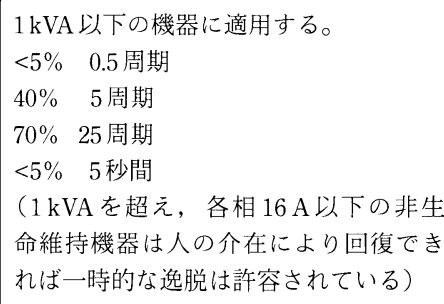 \\
\hline RF 伝導妨害 & IEC 61000-4-6 & 検討中 & $\begin{array}{l}3 \mathrm{~V}(150 \mathrm{kHz} \sim 80 \mathrm{MHz}) \\
\text { 遮蔽室内でのみ使用する機器またはシ } \\
\text { ステムは遮蔽効果値に応じて緩和。た } \\
\text { だし, 最小 } 20 \mathrm{~dB} \text { の遮蔽効果が確保され } \\
\text { ている場合にのみ適用される。 }\end{array}$ \\
\hline 電源周波数磁場 & IEC $61000-4-8$ & 検討中 & $3 \mathrm{~A} / \mathrm{m}(50 / 60 \mathrm{~Hz})$ \\
\hline
\end{tabular}

$2.5 \mathrm{GHz}$ の全帯域にわたって満たすことが要求されていた が，対象機器／システムに必要な緩和帯域は非常に狭く (MRIの例では 50 500 MHz 程度)，このままでは過剩な設 備要求となって遮蔽室の設置に対する技術的, 経済的な問 題が生ずるおそれがあるとする日本の反対コメントにより
対象機器 ノシステムに必要な緩和帯域に絞って規格化され ることになった。具体的には, 緩和を必要とする帯域を超 える周波数範囲（少なくとも 1 decade）以上において $20 \mathrm{~dB}$ 以上の遮蔽効果を有すること, その周波数範囲外での緩和 は $0 \mathrm{~dB}$ とする。 
(2)高調波歪：IEC 61000-3-2

(3)電圧変動, フリッカー： IEC 61000-3-3

(2), (3) と屯各相 $16 \mathrm{~A}$ 以下の定格入力電流を持つ商用電源 系に接続する医療電気機器に適用する。 $220 \mathrm{~V}$ 以上の商用 電源系に接続される医療電気機器への適用となり，100 V 系機器は適用されない。

(2) イミュニティ試験項目

(4)静電気放電：IEC 61000-4-2

第 1 版では気中放電 $8 \mathrm{kV}$, 接触放電 $3 \mathrm{kV}$ の 2 点を試験。第 2 版では気中放電 $\pm 2 \mathrm{kV}, \pm 4 \mathrm{kV}, \pm 8 \mathrm{kV}$ および接触放電 $\pm 2 \mathrm{kV}, \pm 4 \mathrm{kV}, \pm 6 \mathrm{kV}$ の合計 12 点の試験になった。

(5)放射 RF 電磁界：IEC 61000-4-3

周波数範囲は第 1 版の $26 \mathrm{MHz} 1 \mathrm{GHz}$ が第 2 版では 80 $\mathrm{MHz} \sim 2.5 \mathrm{GHz}$ へと大幅に拡大された。26〜80 MHzの範囲は IEC61000-4-6（周波数範囲 $150 \mathrm{kHz} \sim 80 \mathrm{MHz}$ ）に包含され， 両規格によって $150 \mathrm{kHz} \sim 2.5 \mathrm{GHz}$ までがカバーされる。上 限周波数は携帯電話および無線 LAN, Bluetoothなどとの共 存を意図して IEC/TC77で検討され，一般規格の上限は $2 \mathrm{GHz}$ となった。SC62A/WG13（医療機器 EMC）としては Bluetooth や無線 LAN（2.45 GHz 帯）等が病院内に導入され ることは必至と見て，いち早く $2.5 \mathrm{GHz}$ としている。日本 としては，前倒しで対応を規定しても医用電気機器程度の 売り上げ規模では社会的なインフラが整わない，対策の結 果として医用電気機器自身が大きく, 重く, 高価になりか ねないことから反対し，TC77の動向に従うように提案した が覆すには至らず，上限 $2.5 \mathrm{GHz}$ が決定された。新しい上 限周波数まで試験可能なサイトはまだ非常に少ない現状で ある。

許容値は非生命維持機器では $3 \mathrm{~V} / \mathrm{m}$ と変更ないが，生命 維持機器ではすべての周波数範囲で $10 \mathrm{~V} / \mathrm{m}$ と高く設定され た。

(6)ファーストトランジェントハバースト：IEC 61000-4-4

電源ラインの許容值が $\pm 1 \mathrm{kV}$ から $\pm 2 \mathrm{kV}$ に，信号線では $\pm 0.5 \mathrm{kV}$ が $1 \mathrm{kV}$ にそれぞれ引き上げられた。 $3 \mathrm{~m}$ 未満の信 号線と患者接続ケーブルには適用されない。

(7)サージ： IEC 61000-4-5

電源-アース間の許容值が $\pm 2 \mathrm{kV}$ から $\pm 0.5 \mathrm{kV}, \pm 1 \mathrm{kV}$ に, ライン間では $\pm 1 \mathrm{kV}$ が $\pm 0.5 \mathrm{kV}, \pm 1 \mathrm{kV}$ にそれぞれ試験が拡 大された。

(8) RF 伝導妨害：IEC 61000-4-6

非生命維持機器では $150 \mathrm{k} \sim 80 \mathrm{MHz}$ の間で $3 \mathrm{~V}$, 生命維持 機器では $150 \mathrm{k} \sim 80 \mathrm{MHz}$ の間で $3 \mathrm{~V}$, かつ同周波数範网内の ISM周波数では $10 \mathrm{~V}$ となった。

(9)電压ディップ, 瞬断, 電圧変動：IEC 61000-4-11

当初, 電圧ディップ $100 \% 0.5$ サイクルの試験が課せられ ていたが，多くの産業機器では電压ディップ $100 \%$ での試 験は採用されていない，実際の現場では電源ラインのイン ピーダンスのために十分に突入電流を供給できない設備が

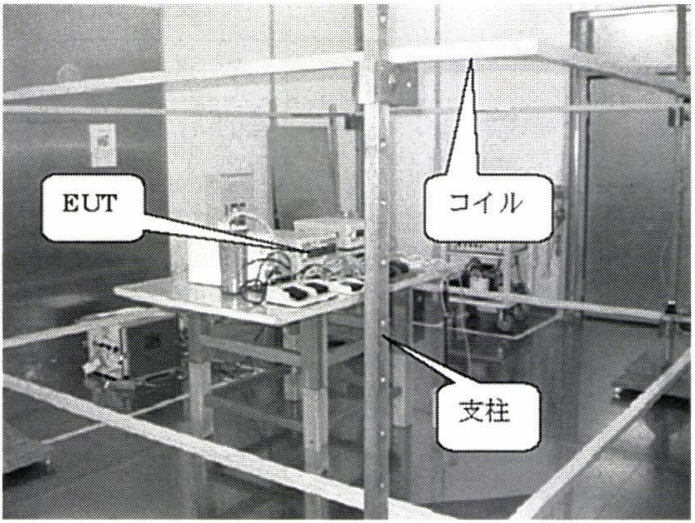

図1. IEC 61000-4-8 試験用コイル

$3 \mathrm{~m}$ 角のコイルを 4 本の支柱で支元る。コイルはXYZの 3 次元方 向に付け替えて試験する。組み立て，付け替えは1人では難し く, 2 人がかりとなる。

これでも収まらないEUT（被試験機器）の場合には，さらに大 きなコイルおよびシールド室が必要になる。1 m 角を超えるコ イルは市眅されておらず，特注または自作となる。

むしろ当たり前であり，医療現場での苦情は発生していな い，などの理由から電压ディップ 100\%での試験を止める， あるいは注意事項として記載するように働きかけた結果， 「電圧ディップ $95 \%$ 以上，0.5 サイクル」に修正された。

すべての生命維持機器および入力電力 $1 \mathrm{kVA}$ 以下の非生 命維持機器に適用する。 $1 \mathrm{kVA}$ 超，かつ各相 $16 \mathrm{~A}$ 以下の非 生命維持機器では一時的な逸脱が許容される。各相 $16 \mathrm{~A}$ 超 の非生命維持機器では適用が免除される。

(10)電源周波数磁場：IEC 61000-4-8（図 1）

コイルで発生させた $3 \mathrm{~A} / \mathrm{m}$ の磁場中にEUTを置き医療電 気機器の動作状況を観察するのであるが， $1 \mathrm{~m}$ 角のコイル 中に置くことのできる医療電気機器は卓上型に限られ, 多 くの医療電気機器では $2 \mathrm{~m}$ 角, $3 \mathrm{~m}$ 角のコイルを必要とし, 広い試験スペースが要求される。実験の結果, CRT を有す る医療電気機器では管面のトレース幅が太くなるなどの影 響が見られる。モニターとして多くのCRTを使用する情報 機器分野でも重大な問題であり，CRTについては許容值を $1 \mathrm{~A} / \mathrm{m}$ と規定している。医療電気機器についても同様な配 慮が望まれたが医用電気機器ではCRTむ含めて規格は $3 \mathrm{~A} / \mathrm{m}$ となった。情報機器業界からCRTを購人・使用する ことの多い医療機器業界側が対策を加える必要があり，技 術的，経済的に負担となろう。

(3) イミュニティ判定基準

【基本性能 (Essential Performance)を与え，かつ，安全が 維持できること。基本性能および安全性に関連した劣化は 許容しない】

これには「許容できない劣化」の例（表3）が11も添え てあり，第 1 版の「危害が生じない，または，危害が生じ ず，かつ製造業者の指定した機能を維持する」という基準 からは大幅に厳しくなっている。電気メスなどの治療機器 においては，外部からのノイズを受けるなどして正しい制 
表 3. 許容できない劣化のリスト

\begin{tabular}{|c|c|}
\hline 1 & 部品の故障 \\
\hline 2 & プログラムできるパラメータの变化 \\
\hline 3 & 工場での既定値へのリセット \\
\hline 4 & 動作モードの変化 \\
\hline 5 & 誤った警報 \\
\hline 6 & 意図した機能の停止（たとえ警報を伴っても） \\
\hline 7 & $\begin{array}{l}\text { 意図しないか, 制御しない動きを含め, 意図しない機能の始動 } \\
\text { (たとえ警報を伴っても) }\end{array}$ \\
\hline 8 & 診断, 治療または処置に大きな影響を与える誤った数值表示 \\
\hline 9 & $\begin{array}{l}\text { 波形上に現れる, 生体信号之識別できない雑音, または生体信 } \\
\text { 号の解読に干渉するような歪 }\end{array}$ \\
\hline 10 & $\begin{array}{l}\text { 画像上に現れる，生体信号と識別できないアーチファクト，ま } \\
\text { たは生体信号の解読に干渉するようなアーチファクトまたは歪 }\end{array}$ \\
\hline 11 & 自動診断または治療用機能の故障（たとえ警報を伴っても） \\
\hline
\end{tabular}

御が保証できない状態になると, 出力を停止して人体への 損傷を避けるなどの安全モードへの移行が仕様として組み 込まれている。表 3 の 4 「動作モードの変更」が生じては ならないとすると, 安全モードへの移行が認められず, 多 大な技術的, 経済的負担が生まれ, 新製品開発への影響が 甚大である。

「基本性能」(Essential Performance)をリスク分析を用い て抽出するにあたって，その判断基準は明確になっていな い。したがって機器により, 製造業者により, また試験機 関により判断が異なることが予想される。これらを整合し て適切な「基本性能」を規定し, 該当機能の合否判断ができ るようにするための検討が今後重要となる。

\section{(4) 機器および取扱説明書の表示・記載事項}

安定した $\mathrm{EMC}$ 環境を確立し, 維持するためには医療機 器のEMC 性能だけではなく, ユーザである医療従事者の使 い方との協調も大切である。正しい情報をユーザに提供す るために, 非常に多くの記載事項が求められている。

(1)接続ケーブルの限定

医療電気機器に使用するケーブル類, プローブ類を医療 電気機器企業の推奨品に限定し，そのケーブル類との組み 合わせで EMC 性能を保証するものである。ケーブル類，プ ローブ類と医療電気機器本体が同一企業でない場合には放 射の増大, イミュニティの減少のおそれがある旨を顧客ま たは使用者に対する警告として記載する。

(2)エミッション適合規格表

製品ごとに異なる適用規格，許容值レベルおよびどのよ うな電磁環境での使用を意図しているかなどを記載してき めこまかくユーザに正しいEMC 情報を提供する。本規格の 附属書には記入例が掲載してある。エミッション適合規格 の例としてはグループ 1 の例, グループ 2 の例, 電磁遮蔽 室内で使用する機器の例があげられている。

\section{(3)近接して使用するときの注意}

「極めて接近して他の（医用）電気機器と使用すること が必要な場合には, その位置関係での正常な作動を確認す ること」と規定されている。すべてが同一企業製品であり， そのような状況で使用することを意図したシステムであれ ば当然, そのような形態で試験がされているであろう。異 種企業製品で構成する場合にはユーザが確認をする必要が あり，医療機関の EMC管理者に情報として記載すること が要求されている。

(4)低いイミュニティレベルの採用の正当性

イミュニティレベルの緩和条件として「重要な物理的, 技術的, 生理的な正当性が立証できる場合は, 要求レベル より低いイミュニティレベル (Lower Immunity) を採用して もよい」とされている。この場合の正当性とは，「物理的 に矛盾している」,「現在の技術では達成不可能」というレ ベルの事実が必要であり, $\mathrm{A}$ 社ができて, B 社ができない といった理由では当然認められない。

さまざまな理由により，低イミュニティレベルを採用し た医療電気機器と通常レベルの医療電気機器を手術室内に 配置する場合には, どのようにすればよいのだろうか。本 当に使用現場で必要な情報は何なのか，どのような情報を， どのように表現すれば有用なのであろうか。医療現場での 実態に合わせた情報提供が望まれるが，膨大な組み合わせ に対して完璧な回答は困難である。

(5)イミュニティ適合規格表

製品ごとに異なる適用規格，適合レベルおよびどのよう な電磁環境での使用を意図しているかなどを記載してきめ こまかくユーザに正しいEMC 情報を提供する。本規格の附 属書には記入例が揭載してある。何らかの電磁的影響が あった場合の考え方, 対処方法なども記載することができ るようになっている。電磁遮蔽室内で使用する MRIの記載 例もあり, 電磁遮蔽室の遮蔽効果の記載方法を検討する良 い例である。

(6)携帯電話等からの分離距離に関する情報（図2） 試験項目としては規定されていないが，医療電気機器を

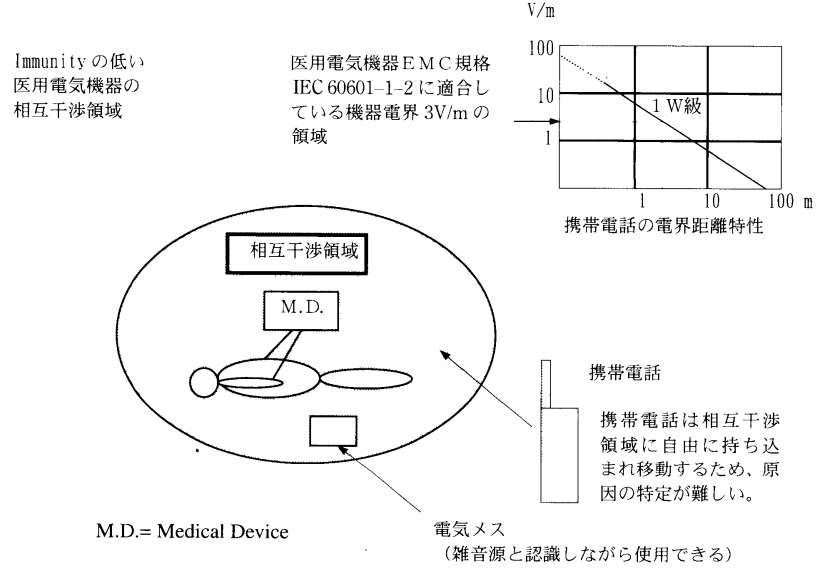

図2. 医用電気機器と携帯電話の相互干渉領域 
携帯電話からどれだけ離せば影響を受けないかという距離 を記載することが求められている。計算式による值を推奨 值として記載することになる。もし, 测定をするとなると 電波暗室を使用し, 多くの携帯電話などを模擬する試験機 器を導入する必要がある。測定器, 試験方法についての規 格も制定せねばならず現実的ではない。また，ここに記入 される計算值は何もない部屋に 1 台の医療電気機器を置い た場合の例であり, 多くの医療電気機器や人々が存在する 部屋の中では影響が異なるであろう。この資料の使い方に ついての研究が重要亡なる。

(7)ESDに敏感な機器, 部品に関する注意および使用に対 する指示

下に示すような ESD警告シンボルを機器本体の触れられ たくない部位に表示し，「これらに触れる必要のある病院 スタッフ (ユーザ) には ESD 予防手順を訓練する必要があ る」という警告を記述すべきとされる。リストストラップ を手首に巻き，一端をアースに接続するなど, ESDの基礎 知識や予防処置の必要事項を記述し, 訓練はユーザに委ね ることになっている。病院内での EMC 管理者など管理体制 が必要となる。

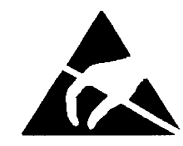

\section{3 第 2 版規格の採用動向}

各国の医療機器規制はまだ第 1 版を採用しているが，先 進国を主体に第 2 版への移行が始まっている。

(1) MDD (欧)

2001/11にEN 60601-1-2: 2001 として制定・発行するとす ぐに2002/1 Official Journal（EU官報）により第2版を調和 規格として宣言した。2004/11には第2版が強制規格となる (第1版を廃止)。

(2) FDA (米)

2002/1 に Recognized Consensus Standard として第2 版を 採用，即座に第 1 版が廃止された。ただし，移行措置期間 があり, MDD と歩調を合わせて 2004/11までとなる見込み。

(3) 薬事法 (日)

やっと第 1 版により法制化したばかりであるが，JIS 第 2 版の原案作成が進んでいる。2005/10 頃にJIS第2版制定・ 発行に漕ぎ着け，同時に EMC 規格適合をJIS 第 2 版に移行 予定。

\section{4 医用電気機器個別規格IEC 60601-2 シリーズ}

社会的な情勢の変化に伴い一般規格がますます高いレべ ルを目指す中で, 医学効果や扱う生体信号のレベルなどに より製品群規格を満たすことが困難な医用電子機器や, 逆 により高いレベルを必要とする医用電子機器も数多くある。 これらの機器は製品別に，その製品の事情を反映させた個 別規格を設けている。個別規格で定めた内容は製品群規格 の規定より優先する。現在, ドラフトを含めて 50 製品を超
える個別規格が作られている。

ほとんどの個別規格では IEC 60601-1-2 を適用することに しているが，なかにはIEC 60601-1-2 (1993)，すなわち第 1版 を適用することを強調しているものもある。

個別規格の中で特に多い項目がClass A/B, Group 1/2 の指 定であり，他には静電気放電の試験電圧指定，放射無線周 波電磁界イミュニティの周波数範囲, 変調周波数, 磁界イ ミュニティの許容值などが規定されている。

磁界イミュニティの許容值については非常に高く設定 （80A/m以上）されている点が目立つ。特に輸液ポンプ IEC60601-2-24の許容值 $(400 \mathrm{~A} / \mathrm{m})$ は驚異的である。全体に 製品群規格よりも厳しい方向に規格を設定しており，まだ 第2版でも採用されていない規格を採用している個別規格 もあるなど, 医用電気機器の使用形態, 電磁環境などの変 化に対する医療現場の声に応えている様子がうかがえる。

外科手術で一般的な電気入スはそもそも高電圧, 高周波 の放電によって止血をしつつ切開をする医療機器であり, そのエミッションノイズを抑えることは電気メスの機能を 停止することになる。したがって電気メスの個別規格 IEC 60601-2-2ではEMI（エミッション）はスタンバイ時のみ適 用することになっている。除細動器 IEC 60601-2-4, 体外衝 撃波結石破砕装置 IEC 60601-2-36など電磁エネルギを発す る医療機器では同様にEMIを緩和している。

放射 RF 電磁界試験 IEC 61000-4-3 では $1 \mathrm{kHz}$ で変調するこ とになっているが，心電計のように生体信号を観測・記録 する医療機器においては生体信号に近い変調周波数の方が 実用的な試験が行えることから IEC 60601-2-25 では $10 \mathrm{~Hz}$ で 変調することになっている。IEC 60601-2-30 非観血血圧計, IEC 60601-2-47 ホルター心電計のように1 $5 \mathrm{~Hz}$ で変調する 機器もある。

\section{4. おわりに}

さまざまな電波利用機器等の普及により新たな電磁波源 も増加して, 周囲の電磁環境はますます複雑に, 医用電子 機器にとってより厳しい状況になりつつある。病院自身も 効率的で安全な医療のためのIT革命を必要とし，これの副 作用亡して病院内への無線機器の持ち込みが行われつつあ る。また，医用電子機器はより患者にやさしい診断・治療 を目指してより精密に，より高度になり，ますます低レべ ル信号を扱い, 複雑な機能を盛り込んでいる。 $\mathrm{EMC}$ 的には 特別な保護を必要とする機器もあり, 診断・治療のメリッ トと対策のデメリットとのトレードオフに直面している。

これまで病院内にあった医用電子機器が在宅医療の進展 とともに家庭に入り, QOLの観点からは医用電子機器を身 に付けた患者が外に出て行くなど，医用電子機器の周囲を 特別な場所として保護することが困難な状況になりつつあ る。病院内, 家庭, 職場はおろか外出先にまで医療機器を 安全に, 効果的に利用できる環境が求められている。情報 
機器をはじめ, すべての電気機器との間で EMC（電磁両立 性）の言葉どおり，まさに両立のための工夫と努力が今こ そ求められている。安全な医療のための EMC 環境亡使用環 境の構築が必要とされる。

(2003.2.12-受理)

\section{用語解説}

医療機器指令：MDD (Medical Devices Directive)

欧州 $\mathrm{EU}$ 議会が発する指令（法律）であり, 医療機器に 対する規制。合格した製品にはCEマークの貼付が許され， EU内での販売ができる。

食品・医薬品局：FDA (Food and Drug Administration) 米国厚生省(DHHS)に属する医療機器等に関する規制を実 施する部局。規模は非常に大きい。

一般規格：IEC 規格に関しては，多くの分野に共通する規格 をいい，本稿では EMC の試験規格である IEC 61000-3-シ リーズのエミッション規格, IEC 61000-4-シリーズのイミュ ニティ規格のこと。ちなみに, 本稿で述へる医療機器に関 する IEC 60601-1-2のように特定の分野に関する規格は製品 群規格と呼ばれ，IEC 60601-2-シリーズのように特定製品に 関する規格を製品規格または個別規格という。規格の適用 は一般規格より製品群規格が優先し, 個別規格が存在する 製品は個別規格が最優先となる。

核磁気共鳴診断装置：MRI (Magnetic Resonance Imaging)

人体に強磁場を与え, 各細胞が持つ磁父特性を利用した 画像診断法により生体に危害を加えず診断ができる装置。 身体を輪切りにしたような画像を得, 少しずつずらして3 次元的な画像を構成することもできる。

コンピュータ断層撮影装置 : CT (Computed Tomography) 従来のエックス線撮影亡異なり, 骨, 液体成分, 空気な よ゙を細かく濃淡として表すことができ, 敇, 肺, 内臓など の疾患の診断が飛躍的に向上した, 生体に危害を加えず診
断ができる装置。

グループ 1 機器 : Group 1 Device

その装置が発する電磁波放射（エミッション）が意四的 ではない医療機器。多くの医療機器は制御のためのコン ピュータを搭載するなど, 高周波を使用し, 機器からは医 療機器としては不要な電磁放射が行われる。この電磁放射 の削減が $\mathrm{EMC}$ 対策。

グループ 2 機器 : Group 2 Device

MRIのように診断のために強力な電磁波放射（エミッ ション）を意四的に行う医療機器。この電磁放射をなくす ことは医療機器としての機能をなくすため, エミッション 限度值の緩和が認められている。電磁遮蔽室内で使用され ることが多い。

調和規格：Harmonized Standards

MDDのための適用規格として EUが認めている規格のこ と。

クオリティ・オブ・ラィフ : QOL (Quality Of Life)

医療側のみの価值判断で治療, 処置が行われることに対 して, 患者や家族の人生観や価值判断を優先させ, 生命, 生活, 人生の質的内容を重んずるべきことを医療や福祉の 現場で主張するバイオエシックス (生命倫理) の考え方。 緩和医療（苦痛の緩和）や機能温存手術法などが, 患者 QOL を重視した治療法とされている。

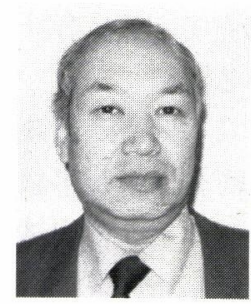

谷川 廣治（たにかわこうじ）

昭和 22 年生まれ。昭和 46 年, 静岡大学工短部電 子工学科卒業。現在, オリンパス光学工業株式会 社医療システムカンパニーにおいて，医療機器に 関する法規制の対応に従事。 